\title{
Characterization of PHBV films loaded with FO1 bacteriophage using polyvinyl alcohol-based nanofibers and coatings: A comparative study
}

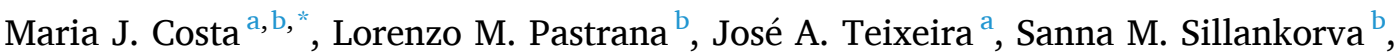 \\ Miguel A. Cerqueira ${ }^{\mathrm{b}}$
}

${ }^{\text {a }}$ Centre of Biological Engineering, University of Minho, Campus de Gualtar, 4710-057 Braga, Portugal

${ }^{\mathrm{b}}$ International Iberian Nanotechnology Laboratory, Av. Mestre José Veiga, 4715-330 Braga, Portugal

\section{A R T I C L E I N F O}

\section{Keywords:}

Active packaging

Antimicrobial

Film

Coating

Nanofiber

Biodegradable

\begin{abstract}
A B S T R A C T
There is a current demand for novel active food packaging solutions using biodegradable materials and no chemical antimicrobial compounds, to ensure food quality and safety. This work involved the incorporation of Salmonella Enteritidis bacteriophage Felix 01, for potential use as an anti-Salmonella agent, into polyvinyl alcohol $(\mathrm{PVOH})$ coatings and fibers deposited by casting and electrospinning on polyhydroxybutyrate/polyhydroxyvalerate (PHBV) films. PHBV films (pristine, with coating, and with nanofibers) were characterized in terms of water sensitivity, mechanical performance, morphology, and thermal properties. Additionally, X-ray diffraction and Fourier Transform Infrared Spectroscopy were performed to assess possible chemical modifications on PHBV films after PVOH deposition and the presence of bacteriophage. PVOH increased the moisture content from 5.98\% (PHBV) to 8.94\% and 8.28\% for PHBV/coating films and PHBV/nanofiber films respectively, increased the solubility from $0 \%$ (PHBV) to $30.32 \%$ (PHBV/coating films) and to $32.42 \%$ (PHBV/nanofiber films), and increased the hydrophilicity of the films (contact angle of $76.31^{\circ}$ for $\mathrm{PHBV}, 64.01^{\circ}$ for $\mathrm{PHBV} / \mathrm{coating}$ films and $30.90^{\circ}$ for $\mathrm{PHBV} /$ nanofiber films), leading to an increased water affinity of their surface. Felix $\mathrm{O} 1$ was successfully added and maintained antimicrobial activity ( $10^{6}$ titer) after the formation of the coating and nanofibers, demonstrating that these solutions can potentially be used in future packaging materials to avoid Salmonella contamination.
\end{abstract}

\section{Introduction}

The food industry is continuously changing to improve the quality and safety of food products. One of the major problems in the food industry is microbial contamination that leads to food spoilage and foodborne illnesses (Alves et al., 2018; Cerqueira, Costa, Fuciños, Pastrana, \& Vicente, 2014; Cerqueira, Costa, Rivera, Ramos, \& Vicente, 2014; World Health Organization, 2020). Facing a panorama where foodborne diseases increase due to bacterial contaminations, particularly due to Salmonella (World Health Organization, 2018), there is an emerging need to find improved strategies to maintain food safety standards for the consumers. The food packaging industry has been searching for novel solutions to reduce bacterial contamination through the use of different types of antimicrobial agents, having proved efficacy in preventing pathogenic bacterial growth (Alves et al., 2018; Becerril, Nerín, \& Silva, 2020; Yousefi, Ehsani, \& Jafari, 2019; Taylor, 2018).
Bacteriophages are antimicrobial viruses recognized to have high effectiveness in controlling pathogenic bacteria growth and great potential to be used in the food industry (Sillankorva, Oliveira, \& Azeredo, 2012a, 2012b). Bacteriophages are safe, have a high specificity against a target (e.g. Salmonella Enteritidis), self-replication capacity, are easily isolated, purified, produced, and have a long shelf-life (Sillankorva et al., 2012a, 2012b). Bacteriophages with a lytic cycle, characterized by an infection and multiplication inside the bacterial host that causes bacterial lysis and the consequent release of new virus particles, are the best option to ensure food safety due to their harmless properties (Kim, Jo, \& Ahn, 2015). Due to the extensive use of antibiotics and the continuous rising of bacterial resistance, and the increase of superresistant bacterial strains, bacteriophages are becoming a subject of great interest due to their effectiveness in reducing bacterial contamination, and easy screening. Since bacteria can become resistant to bacteriophages, to circumvent this problem, it is possible to use

\footnotetext{
* Corresponding author at: Centre of Biological Engineering, University of Minho, Campus de Gualtar, 4710-057 Braga, Portugal; International Iberian Nanotechnology Laboratory, Av. Mestre José Veiga, 4715-330 Braga, Portugal.

E-mail address: mariacosta@ceb.uminho.pt (M.J. Costa).
} 
bacteriophage cocktail formulations to minimise the emergence of bacterial resistance. Therefore bacteriophage products with GRAS (generally recognized as safe) status are increasing in numbers, allowing their use in the food industry (Śliwka et al., 2019). Bacteriophage Felix O1 can infect different Salmonella serogroups already described by Kallings (1967) and also infects different species like $S$. agona, $S$. anatum, S. Dublin also described by Hirsh and Martin (1983).

The low stability of bacteriophages in food environment conditions is the main constraint that limits their use as food antimicrobial agents (Huang \& Nitin, 2019). Novel solutions have been suggested to solve this issue, namely the use of carriers for bacteriophages such as films, coatings and nanofibers made with biodegradable materials using different methods like spreading and electrospinning (Alves et al., 2018; Alves, Cerqueira, Pastrana, \& Sillankorva, 2020; Malik et al., 2017; Malik et al., 2017). Although there are several bacteriophage encapsulation studies, their application is more related to sanitizing and veterinary applications (Huang \& Nitin, 2019; Malik, Sokolov, Mancuso, et al., 2017; Malik, Sokolov, Vinner, et al., 2017).

Biodegradable polymers like polyvinyl alcohol (PVOH) and polyhydroxybutyrate/polyhydroxyvalerate (PHBV) are well-established packaging polymers that have excellent properties for use in food packaging (Cerqueira, Costa, Fuciños, et al., 2014; Cerqueira, Costa, Rivera, et al., 2014; Wen et al., 2016). PVOH is non-toxic, biodegradable, and highly hydrophilic. It is a biocompatible semi-crystalline polymer with excellent mechanical, thermal, and permeability properties that allow homogenous nanofibers production by electrospinning (Hirsch et al., 2019). PHBV is a natural polymer with high crystallinity and presents a relatively high gas and water barrier, being a suitable replacement for polyolefins in many food packaging applications (Cherpinski, Torres-giner, Lagaron, Cabedo, \& M, 2017). Studies performing the functionalization of biodegradable polymers using a casting technique showed promising results (Massaro, Cosentino, Terzi, Marcianò, \& Capodieci, 2015; Wang et al., 2020). Peris (2018) combined PHBV with polylactic acid (PLA) and starch and antimicrobial compounds like carvacrol and eugenol. Antimicrobial activity was observed, and suitable mechanical and water permeability properties were achieved. Regarding the electrospinning technique, the literature studies show promising results to functionalize biodegradable polymers (Cerqueira et al., 2016a; Cerqueira et al., 2016b; Figueroa-Lopez et al., 2020). Balik, Argin, Lagaron, and Torres-Giner (2019), used PHBV as external layers and pectin films produced by electrospinning and observed that the whole structure was annealed and the barrier performance to water vapour and limonene was enhanced. Electrospinning is a very effective process to produce bio-based nanostructures with different sizes (micro to nano) and different structures (fibers and particles) with no temperature or solvent requirement, presenting a great advantage when incorporating bacteriophages that are sensitive to temperatures and solvents (Costa et al., 2017).

Studies using bio-based systems with the incorporation of bacteriophages are still very scarce, and the use of electrospinning to incorporate bacteriophages in nanofibers or nanoparticles is considerably unexplored. Therefore, the main objective of this work was to develop PHBV films functionalized with Felix $\mathrm{O} 1$ bacteriophage loaded in PVOH-based nanofibers and coatings. The developed Felix $\mathrm{O} 1$ bacteriophage loaded films were then evaluated in terms of their physicochemical properties and antimicrobial activity against $S$. Enteritidis.

\section{Experimental}

\subsection{Materials}

Polyvinyl alcohol (PVOH) 98\% - 99\% hydrolyzed with a molecular weight $\left(M_{w}\right) 31,000-50,000$ and the gelatine (G9391, Type B - bovine skin) were obtained from Sigma-Aldrich (Portugal), Polyhydroxybutyrate/ Polyhydroxyvalerate 8\% -Biopolymer (PHBV) films was purchased from Goodfellow Cambridge Limited (Huntingdon,
England).

Tris base was purchased from Fluka (Portugal), sodium chloride $(\mathrm{NaCl})$, magnesium sulfate heptahydrate $\left(\mathrm{MgSO}_{4} .7 \mathrm{H}_{2} \mathrm{O}\right)$ were obtained from Panreac Applichem (Spain).

Bacteriophage Felix O1 was kindly provided by Micreos (Netherlands), and Hospital de Braga provided the $S$. Enteritidis (H40499 SDE) used in this work.

\subsection{Preparation of $\mathrm{PVOH}$ solution with bacteriophage Felix $\mathrm{O1}$}

PVOH solutions were prepared as described by López-Rubio, Sanchez, Sanz, and Lagaron (2009) with some modifications. Briefly, PVOH solutions were prepared by dissolving $14 \%(w / v)$ of $\mathrm{PVOH}$ in sterile SM buffer $\left(100 \mathrm{mmol}\right.$ of $\mathrm{NaCl}, 8 \mathrm{mmol}$ of $\mathrm{MgSO}_{4} .7 \mathrm{H}_{2} \mathrm{O}$, and $50 \mathrm{mmol}$ of Tris-hydrochloride ( $\mathrm{pH} 7.5)$ with $0.01 \%(\mathrm{w} / \mathrm{v})$ of gelatine under agitation at $80{ }^{\circ} \mathrm{C}$ for $2 \mathrm{~h}$. SM buffer was selected as a solvent to preserve the bacteriophage active inside the matrices for a longer time.

Later, the solution was submitted to UV light for $15 \mathrm{~min}$ to ensure the sterilization of the solution before the addition of bacteriophage Felix O1. Afterward, $1 \%(v / v)$ of Felix 01 bacteriophage with a concentration of approximately $10^{10} \mathrm{PFU} \mathrm{mL} \mathrm{m}^{-1}$ was added, and the solution stirred again for $30 \mathrm{~min}$. $\mathrm{PVOH}$ solutions without bacteriophage were used as control. The PVOH solutions were stored at $4{ }^{\circ} \mathrm{C}$ before further use.

The $14 \% \mathrm{PVOH}$ concentration was chosen based on preliminary studies where the $\mathrm{PVOH}$ solution was able to form nanofibers in the electrospinning process and form homogeneous coatings with the casting method.

\subsection{Preparation of electrospun $P H B V /$ nanofiber films}

For the electrospinning process, the PVOH solution with Felix O1 with a titer of $10^{9} \mathrm{PFU} / \mathrm{mL}$ was transferred to a $10-\mathrm{mL}$ plastic syringe with a stainless steel needle $(\varnothing 1.07 \mathrm{~mm})$ and then directly electrospun ( $25 \mathrm{kV}$, and $0.3 \mathrm{~mL} \mathrm{~h}^{-1}$ ) onto $25 \mathrm{~cm}^{2}$ square PHBV films, during $1 \mathrm{~h}$. The distance between the needle and the plate was $10 \mathrm{~cm}$, and experiments were carried out at room temperature $\left(20{ }^{\circ} \mathrm{C}\right)$. The electrospinning apparatus was a NanoNC, eS-robot (NanoNC, Korea). These electrospinning conditions, voltage, flow rate, and distance between the needle and the plate used were based on the work described by Salalha, Kuhn, Dror, and Zussman (2006), but further optimized to obtain homogeneous nanofibers, bead free nanofibers, with a diameter $\pm 100 \mathrm{~nm}$, able to incorporate the bacteriophage (see Supplementary Information for more information).

Before all analyses, $\mathrm{PHBV} /$ nanofiber films were conditioned in desiccators containing a saturated solution of $\mathrm{Mg}\left(\mathrm{NO}_{3}\right)_{2} \cdot 6 \mathrm{H}_{2} \mathrm{O}$ at $53 \%$ of relative humidity $(\mathrm{RH})$ at room temperature $\left(\approx 20{ }^{\circ} \mathrm{C}\right)$ for $24 \mathrm{~h}$. For bacteriophage analyses, the PHBV/nanofiber films were stored at $4{ }^{\circ} \mathrm{C}$ for further experiments.

\subsection{Preparation of $P H B V /$ coating films}

PHBV/coating films were prepared as described by Ribeiro et al. (2018) and López-Rubio et al. (2009) with some modifications. Briefly, PVOH solution with Felix 01 with a titer of $10^{7} \mathrm{PFU} \mathrm{mL}^{-1}(400 \mu \mathrm{L})$ was spread onto the $25 \mathrm{~cm}^{2}$ PHBV square films using a metal spreader with a surface contact of $7.5 \mathrm{~cm}$ to provide a final thickness of $0.025 \mathrm{~mm}$ (works similarly to doctor blade technique) until complete coverage of the PHBV films. Afterward, the film-forming solution was dried at $30{ }^{\circ} \mathrm{C}$ for $16 \mathrm{~h}$. Before all analyses, PHBV/coating films were conditioned in desiccators containing a saturated solution of $\mathrm{Mg}\left(\mathrm{NO}_{3}\right)_{2} \cdot 6 \mathrm{H}_{2} \mathrm{O}$ at $53 \%$ of relative humidity $(\mathrm{RH})$ at room temperature $\left(\approx 20{ }^{\circ} \mathrm{C}\right)$ for $24 \mathrm{~h}$. For bacteriophage titer analyses, PHBV/coating films were stored at $4{ }^{\circ} \mathrm{C}$ for further experiments. 


\subsection{Colour, opacity and weight gain}

The colour, opacity and weight gain were determined as described by Costa et al. (2018) and Costa et al. (2015). Briefly, the colour of the samples was determined using a Minolta colorimeter ( $\mathrm{Cr} 400$, Minolta, Japan). A white standard colour plate $(\mathrm{Y}=93.9, \mathrm{x}=0.3158, \mathrm{y}=$ 0.3321 ) was used for calibration and as a background. Reflectance measurements evaluated $L^{*}, a^{*}, b^{*}$ values of each film. $L^{*}$ indicates the lightness (ranging from black to white), and the horizontal axes, indicated by $\mathrm{a}^{*}$ and $\mathrm{b}^{*}$, are chromatic coordinates (ranging from $-\mathrm{a}^{*}$ : greenness, $-b^{*}$ : blueness to $+a^{*}$ : redness, $+b^{*}$ : yellowness). Values of $a^{*}$ and $b^{*}$ are close to zero for neutral colours and increase as the colour becomes more chromatic and saturated. The measurements were repeated six times for each type of sample.

To calculate the weight gain after the deposition of PVOH on PHBV films, PHBV/coating films and PHBV/nanofiber films were weighted, and the PVOH was calculated based on Eq. (1).

$P V O H$ weight gain $=$ weight $P H B V($ coating $\mid$ nanofiber $)-$ weight $P H B V$ film

\subsection{Scanning electron microscopy (SEM)}

Following the methodology used by Nunes et al. (2020), the sample morphology analysis was evaluated by SEM. Samples were sputtered with gold (10-nm layer) using a Sputter Quorum Q 15 OR ES (Quorum Technologies, United Kingdom) and placed into an aluminum support using a double-side carbon conductive tape. Samples surface and crosssectional morphology were observed by SEM (Quanta 650 FEG, FEI, USA) using different magnifications with an operating voltage between $5 \mathrm{kV}$ and $10 \mathrm{kV}$. To perform cross-sectional analysis, samples were placed into liquid nitrogen and afterward split.

2.7. Moisture content, water solubility, and water vapour transmission rate (WVTR)

Three replicates were made for each type of sample.

$W V T R=$ slope $/$ sample area

where the slope of weight loss $v s$ time $\left(\mathrm{g} \mathrm{s}^{-1}\right)$ was obtained by linear regression, and sample area $\left(\mathrm{m}^{2}\right)$ corresponds to the area in contact with the water vapour.

\subsection{Surface hydrophobicity}

The hydrophobicity of the surface was determined as described by Cerqueira, Costa, Fuciños, Pastrana, and Vicente (2013). In brief, PHBV/ nanofiber films and PHBV/coating films were evaluated regarding their hydrophobicity, measuring the respective contact angle (measured $0.8 \mathrm{~s}$ after the drop contact with the PHBV surface), using the sessile drop method. The contact angle was determined using a face contact angle meter (OCA 20, DataPhysics, Germany) in which a droplet of ultrapure water was deposited onto the PHBV/nanofiber films and PHBV/coating films functionalized surface using a $500-\mu \mathrm{L}$ precision syringe (Hamilton, Switzerland). The Laplace-Young equation was used to solve and fit the drop profile. At least three independent measurements were done per sample.

\subsection{Mechanical properties}

Tensile strength (TS) elongation at break (EB) and Young's Modulus (YM) properties of the samples were measured using the texture analyzer (TA.HD plus, Stable Micro Systems, United Kingdom) equipment with the software Exponent, following the methodology described by ASTM D882-10 with some modifications, and with an initial distance of $4 \mathrm{~cm}$. The calculations were based on Eq. (5) for TS and Eq. (6) for EB. YM was evaluated as the slope of the initial linear region of stress-strain curves.

$T S(M P a)=$ maximum load $(N) /$ initial cross - sectional area $\left(m^{2}\right)$

$E B(\%)=$ final lenght at the point of sample rupture $(\mathrm{mm}) /$ Initial lenght of the specimen $(\mathrm{mm})$

Moisture content and water solubility were determined by the methods described by Ortiz de Elguea-Culebras et al. (2019), with some modifications. Briefly, squares of $25 \mathrm{~cm}^{2}$ diameter were used to perform these analyses. Samples were weighed before and after being placed at $105{ }^{\circ} \mathrm{C}$ for $24 \mathrm{~h}$. Moisture content was determined based on Eq. (2):

Moisture content $(\%)=(M i-M f) / M i \times 100$

where $M i$ and $M f$ are the weight before and after drying, respectively.

Solubility was determined by placing the dried samples into recipients with $50 \mathrm{~mL}$ of distilled water and shake for $24 \mathrm{~h}$ at $150 \mathrm{rpm}$ at room temperature $\approx 20^{\circ} \mathrm{C}$. The remaining insolubilized samples were dried at $105^{\circ} \mathrm{C}$ for $24 \mathrm{~h}$ and weighed. Solubility was calculated based on Eq. (3):

Solubility $(\%)=(S i-S f) / S i \times 100$

where $S i$ and $S f$ are the weight of the dried sample before the test and after the test, respectively. Three replicates were made for each film.

WVTR was determined based on the methodology described by Costa et al. (2018). Briefly, PHBV/nanofiber films and PHBV/coating films were fitted on a cup device with $50 \mathrm{~mL}$ of distilled water at $0 \% \mathrm{RH}$ and room temperature $\left(\approx 20^{\circ} \mathrm{C}\right)$. The cups' weight was measured every $2 \mathrm{~h}$ until a steady state was reached. WVTR was calculated using Eq. (4).
Samples $(50 \mathrm{~mm} \times 20 \mathrm{~mm})$ were clamped between grips with an initial $40 \mathrm{~mm}$ distance. The force and deformation were recorded during extension at $50 \mathrm{~mm} \mathrm{~min}{ }^{-1}$. Results of the TS and EB were obtained in $\mathrm{MPa}$ and percentage, respectively. At least six replicates of each sample were performed.

\subsection{0. $X$-ray diffraction $(X R D)$}

Crystalline characterization of PHBV/coating films and PHBV/ nanofiber films was done performing X-ray diffraction (XRD) analysis as described by Figueroa-Lopez et al. (2020) with some modifications. Briefly, Malvern Panalytical X Pert PRO MRD diffractometer was used with $\mathrm{Cu}-\mathrm{K} \alpha$ radiation $(\lambda=1.54056 \AA)$ and conditions of $45 \mathrm{kV}$ and 40 $\mathrm{mA}$. Data were collected at room temperature in a $2 \theta$ range from $10.0^{\circ}$ to $60^{\circ}$. Each sample analysis was carried $144.84 \mathrm{~s}$ with a step size of $0.0197^{\circ}$, and the software used to analyze the data was PANanalytical $\mathrm{X}$ 'Pert HighScore Plus.

\subsection{Differential scanning calorimetry (DSC) and thermogravimetric analyses (TGA)}

The crystalline state of the samples was evaluated as described by 
Azevedo et al. (2020). Briefly, DSC measurements were performed in a Perkin Elmer DSC 6000 (Perkin Elmer, Waltman, MA, USA). Approximately $3 \mathrm{mg}$ of the sample was placed in aluminum DSC pans (B0143016). The measurements were performed between $-30{ }^{\circ} \mathrm{C}$ and $200{ }^{\circ} \mathrm{C}$ at a heating rate of $10{ }^{\circ} \mathrm{C} \mathrm{min}^{-1}$ under a nitrogen atmosphere.

Thermal degradation was performed based on the methodology of Freitas et al. (2020) with some modifications. TGA were done with a Perkin Elmer TGA 4000 (Perkin Elmer Waltman, MA, USA). Approximately $4 \mathrm{mg}$ of sample was placed in the balance system and heated from $25{ }^{\circ} \mathrm{C}$ to $400{ }^{\circ} \mathrm{C}$ at a heating rate of $10{ }^{\circ} \mathrm{C} \mathrm{min}^{-1}$ under a nitrogen atmosphere. For each measurement, three repetitions were made for each type of sample. The data was analyzed in Pyris software (version 13, Perkin Elmer Waltman, MA, USA).

\subsection{Fourier transform infrared spectroscopy (FTIR)}

Following the methodology described by Alves et al. (2020), FTIR spectra of the samples were recorded with Bruker Alpha II FTIR spectrometer (Bruker, Germany) measuring in the wavelength range from 400 to $4000 \mathrm{~cm}^{-1}$ at a resolution of $4 \mathrm{~cm}^{-1}$, using Platinum Attenuated Total Reflection mode (ATR) (Bruker, Germany). The absorbance of each FTIR spectrum was normalized between 0 and 1 .

\subsection{Bacteriophage titer in $P H B V /$ coating films and $P H B V /$ nanofiber} films

The titer of bacteriophages was determined using $25 \mathrm{~cm}^{2}$ square $\mathrm{PHBV} /$ coating films and PHBV/nanofiber films. These were placed in an Erlenmeyer flask with $10 \mathrm{~mL}$ of SM buffer and incubated for $1 \mathrm{~h}$ at $25^{\circ} \mathrm{C}$ and $120 \mathrm{rpm}$ to promote their entire release.

The number of bacteriophage plaque forming units (PFU) was determined using the double-layer procedure (Adams, 1959), with some modifications, on S. Enteritidis H40499 SDE bacterial lawns. Briefly, one colony-forming unit (CFU) of $S$. Enteritidis was inoculated onto $5 \mathrm{~mL}$ of TSB and incubated overnight at $37^{\circ} \mathrm{C}$ and $120 \mathrm{rpm}$. An aliquot of $100 \mu \mathrm{L}$ of the overnight culture was put onto a TSA plate, and $4 \mathrm{~mL}$ of TSB top agar [TSA with $0.4 \%$ agar $(w / v)$ ] was poured on top, and the plate tilted to spread the agar evenly. Ten-fold serial dilutions were performed, and $10 \mu \mathrm{L}$ of these dilutions were added to the plate using the teardrop method. The drops were allowed to dry, and the plates were incubated at $37^{\circ} \mathrm{C}$ overnight. The theoretical titer value of Felix $\mathrm{O} 1$ was calculated based on the amount of solution (mL) used to produce the samples and their corresponding titer. At least two replicates were performed.

\subsection{Statistical analysis}

Statistical analysis was performed using the analysis of variance (ANOVA) method, and Statistica software for Windows (version 12, StatSoft Inc., Tulsa, OK, USA) was used to perform Tukey's test to detect differences of means, where $p<0.05$ was considered statistically significant.

\section{Results and discussion}

\subsection{Colour, opacity, and weight gain}

Fig. 1 exhibits the overall appearance of PHBV films, PHBV/coating films, and PHBV/nanofiber films. PHBV/nanofiber films have a higher opacity $(93.5 \%)$ and a white colour with some heterogeneity. Similar values of colour were observed for PVOH nanofibers by Ahmadpoor, Nateri, and Motaghitalab (2013). These colour properties can be related to the higher amount of $\mathrm{PVOH}$ material deposited in the PHBV film, with a different refractive index contributing to the increase in the opacity of the PHBV/nanofibers films (Fabra, López-Rubio, \& Lagaron, 2015). In the same way, the higher thickness of the PHBV/nanofiber films mat (0.056 mm) when compared to PHBV $(0.025 \mathrm{~mm})$ and PHBV/coating films $(0.022 \mathrm{~mm})$ (Table 1$)$ causes a light scattering promoting a higher opacity (Figueroa-Lopez et al., 2020). This increase in thickness can be due to the fiber orientation obtained during electrospinning. Cherpinski et al. (2017) observed that random oriented electrospun nanofibers promote a significant increase of the mat thickness that can explain these results. The similar values obtained for PHBV film and PHBV/ coating films can be explained by the comparable thickness observed for PHBV and PHBV/coating films (Tables 1 and 2, Fig. 2 (b,d,f)).

Regarding weight gain, $\mathrm{PVOH}$ increased the final matrix weight by $44.04 \%$ for PHBV/coating films and $35.79 \%$ for PHBV/nanofiber films (Table 3).

\subsection{Scanning electron microscopy (SEM)}

Fig. 2 shows the surface of electrospun nanofibers deposited in PHBV film. Homogeneous nanofibers were formed when using $14 \%$ of $\mathrm{PVOH}$, SM buffer as a solvent, and $1 \%(v / v)$ of Felix $\mathrm{O} 1$ bacteriophage deposited in PHBV films (Fig. 2). Regarding the cross-sectional view, it is possible to identify the PHBV film and the nanofiber layer and confirm the values of the thickness measured before. Regarding homogeneity, PHBV nanofibers are less homogenous than films and less homogeneous compared to other nanofibers in works using PHBV films and a deposition solution comparing casting $v s$ electrospinning (Balik et al., 2019).

Fig. 2 also presents the surface and cross-sectional image from the $\mathrm{PHBV} /$ coating films produced by spreading. It is possible to observe a homogeneous surface with the two layers visible and good adhesion between PVOH and PHBV. Regarding the cross-sectional image, Peris (2018) found a similar appearance when observing the cross-sectional image of PHBV films.

\subsection{Moisture content, water solubility, and water vapour transmission rate}

It was observed that both PHBV/coating films and PHBV/nanofiber films presented similar moisture and solubility values, but there is a significant difference $(p<0.05)$ between PHBV/coating films and $\mathrm{PHBV} /$ nanofiber films and the PHBV films alone (Table 1). PHBV/ nanofiber films and $\mathrm{PHBV} /$ coating films revealed higher values of
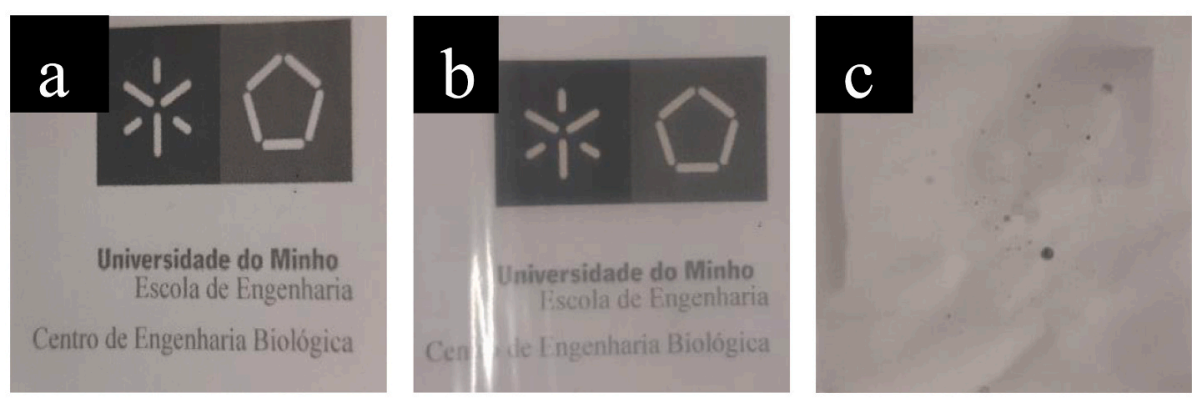

Fig. 1. Selected pictures of PHBV film (a), PHBV/coating films (b) PHBV/nanofiber films (c). 
Table 1

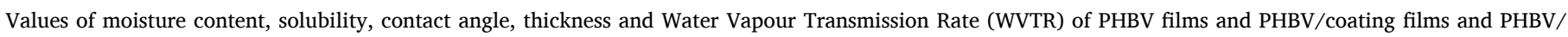
nanofiber films.

\begin{tabular}{|c|c|c|c|c|c|c|}
\hline Matrix & Moisture (\%) & Solubility (\%) & PVOH solubility (\%) & Contact angle $\left({ }^{\circ}\right)$ & Thickness (mm) & WVTR $\times 10^{-3}\left(\mathrm{~g} \mathrm{~s}^{-1} \mathrm{~m}^{-2}\right)$ \\
\hline PHBV (control) & $5.98 \pm 0.9 a$ & $0 \mathrm{a}$ & N.A & $76.31 \pm 0.78 \mathrm{a}$ & $0.025 \pm 0.001 \mathrm{a}$ & $2.52 \pm 0.63 a$ \\
\hline PHBV/coating films & $8.94 \pm 0.51 b$ & $30.32 \pm 5.14 b$ & $68.85 \mathrm{a}$ & $64.01 \pm 3.04 b$ & $0.022 \pm 0.004 a$ & $2.52 \pm 0.63 a$ \\
\hline PHBV/nanofiber films & $8.28 \pm 0.08 b$ & $32.42 \pm 4.11 b$ & $90.58 b$ & $30.90 \pm 1.95 c$ & $0.056 \pm 0.017 \mathrm{~b}$ & $2.10 \pm 0.36 \mathrm{a}$ \\
\hline
\end{tabular}

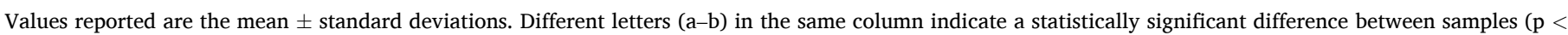
0.05).

Table 2

values of $\mathrm{L}^{*}, \mathrm{a}^{*}, \mathrm{~b}^{*}$ and Opacity for PHBV films and PHBV/coating films and $\mathrm{PHBV} /$ nanofiber films.

\begin{tabular}{lllll}
\hline Matrix & $\mathrm{L}^{*}$ & $\mathrm{a}$ & $\mathrm{b}$ & Opacity (\%) \\
\hline PHBV (control) & $97.49 \pm$ & $-0.09 \pm$ & $2.18 \pm$ & $16.94 \pm$ \\
& $0.04 \mathrm{a}$ & $0.02 \mathrm{a}$ & $0.05 \mathrm{a}$ & $0.32 \mathrm{a}$ \\
PHBV/coating & $97.40 \pm$ & $-0.20 \pm$ & $2.58 \pm$ & $17.50 \pm$ \\
films & $0.09 \mathrm{a}$ & $0.01 \mathrm{~b}$ & $0.05 \mathrm{~b}$ & $0.44 \mathrm{a}$ \\
PHBV/nanofiber & $98.21 \pm$ & $0.03 \pm 0.03 \mathrm{c}$ & $0.75 \pm$ & $93.45 \pm$ \\
films & $0.33 \mathrm{~b}$ & & $0.20 \mathrm{c}$ & $2.10 \mathrm{~b}$ \\
\hline
\end{tabular}

Values reported are the mean \pm standard deviations. Different letters (a-b) in the same column indicate a statistically significant difference between samples $(\mathrm{p}<0.05)$.

moisture and solubility, which is explained by the presence of the PVOH in their surface. PVOH has higher water affinity due to the hydroxyl groups present in its structure and that are responsible for the highaffinity to the water molecules (Abd El-aziz, El-Maghraby, \& Taha, 2017; Weiss, Kanjanapongkul, Wongsasulak, \& Yoovidhya, 2014).

These results show that the nanofiber solubilization was close to complete if we consider the PVOH film solubility (Table 1). PHBV/ coating films were less soluble than the PHBV/nanofiber films (90.58\%) but still present a high PVOH solubility (68.85\%) (Table 1). Since PHBV films are insoluble in water, the differences between the solubility of the $\mathrm{PHBV} /$ coating films and PHBV/nanofiber films were due to the type of $\mathrm{PVOH}$ structure present in each film. The higher surface to volume ratio in the electrospun nanofibers promotes a higher solubility of the material in water due to the larger number of carboxyl groups in $\mathrm{PVOH}$ exposed at the surface (Abd El-aziz et al., 2017; Weiss et al., 2014).

Regarding the water vapour transmission rate (WVTR), the results presented in Table 1 show that no significant differences were found between PHBV, PHBV/nanofiber films, and PHBV/coating films. The values agree with values in the literature for PHBV films (MelendezRodriguez et al., 2018), showing that PVOH nanofibers and coatings have no influence in the water permeability of the developed systems. The low water permeability in PHBV/coating films and PHBV/nanofiber films is maintained due to PHBV films' high hydrophobicity that provides low water vapour permeability characteristics to these systems (Fabra et al., 2015).

\subsection{Surface hydrophobicity}

Results show that there is a difference in the surface hydrophobicity between all the matrices. The major difference was found in the PHBV/ nanofiber films that presented a value of $30.90 \pm 1.95^{\circ}$, revealing a hydrophilic character when compared to PHBV/coating films (64.01 \pm $\left.3.04^{\circ}\right)$ and $\mathrm{PHBV}$ film $\left(76.31 \pm 0.78^{\circ}\right)$ that reflected a lower hydrophilic behaviour (Cerqueira, Costa, Fuciños, et al., 2014; Cherpinski et al., 2018).

The values of PHBV are in agreement with those found in the literature (Cherpinski et al., 2018; Melendez-Rodriguez et al., 2018) related to the surface nature of the polymer indicating water resistance properties. PHBV is a polyhydroxyalkanoate, and it is a linear aliphatic polyester. The presence of $\mathrm{PVOH}$ in the film surface promotes water absorption, causing an increase in the hydrophilicity of the PHBV/ coating films and PHBV/nanofiber films, influencing the surface properties, which is reflected by smaller contact angle values (Table 1).

\subsection{Mechanical properties}

TS, EB and YM values for the PHBV film varied between $21.40 \pm$ $2.04 \mathrm{MPa}, 2.69 \pm 0.32 \%$, and $1335.00 \pm 68.88 \mathrm{MPa}$, respectively (Table 4), and were similar to previously reported results (FigueroaLopez et al., 2020; Kotnis, O’Brien, \& Willett, 1995; Melendez-Rodriguez et al., 2018). The two different deposition strategies influenced the mechanical properties of PVOH films differently. The lower TS and YM values demonstrated that the PHBV/nanofiber films significantly $(p<$ 0.05 ) decreased the sample resistance and stiffness; however, the EB values are maintained. The deposition of PVOH in the PHBV matrix through electrospinning increased the thickness of $\mathrm{PHBV} /$ nanofiber films (Table 1). This change in thickness led to an apparent decrease in TS values because the thickness values are used for the cross-sectional area calculation, and consequently will interfere in TS (Eq. (4)) and YM values. Although there is a slight increase in EB values for PHBV/ coating films compared to PHBV, all the values were low $(\leq 4 \%)$, revealing low flexibility of all matrices, characteristic of matrices like PHBV (Jost \& Langowski, 2015). Melendez-Rodriguez et al. (2018) observed the same behaviour in PHBV films with EB values between $2.6 \%$ for a concentration of $8 \%$ PHBV and $2.9 \%$ for $2 \%$ PHBV with a value of HV around $20 \%$ molar content. Also, Figueroa-Lopez et al., 2020 reported values of $2.4 \%$ EB for neat PHBV with HV molar content of $2-3 \%$. Usually, when a reinforcing material is coupled with a matrix polymer like PHBV film, the EB behaviour shows a decrease probably related to the chain entanglement between the material and the PHBV (Yu, Qin, Sun, Yang, \& Yao, 2014). In this study, since there is no chemical interaction between the PVOH and the PHBV (as demonstrated below in Section 3.8) and the PVOH amount in the final matrix is low, the TS and EB values of PHBV/nanofiber films and PHBV/coating films remain similar to neat PHBV film.

\section{6. $X$-ray diffraction $(X R D)$}

In all samples, one main peak appeared around $13.4^{\circ}$, followed by five other relevant peaks around $17^{\circ}, 22^{\circ}, 25^{\circ}$, and $27^{\circ}$ (Fig. 3). These peaks are found in all samples revealing a semi-crystalline nature. In other work, these peaks were associated with PHB's orthorhombic unit cell (Melendez-Rodriguez et al., 2018). Analysis of the $27^{\circ}$ peak shows a deconvolution in PHBV film and PHBV/nanofiber films while PHBV/ coating films just presents a less sharpened peak probably related to the presence of smaller crystallites present in the sample due to the slower drying process that occurs in the casting process. PVOH is also a semicrystalline structure where the single crystals are bond by disordered polymer chains (Lee et al., 2017). A peak around $19.8^{\circ}$ appears with significant relevance corresponding to (101) reflections of polymer crystalline phases of PVOH and PHBV (Cho, Lyoo, Chvalun, \& Blackwell, 1999; Melendez-Rodriguez et al., 2018; Yu et al., 2014). A peak also appears at $31.6^{\circ}$ for $\mathrm{PHBV} /$ nanofiber films and $\mathrm{PHBV} /$ coating films with FO1 leading to attribute this peak to the $\mathrm{MgSO} 4 \cdot 7 \mathrm{H} 2 \mathrm{O}$ salt present in SM Buffer (Ramalingom, Podder, \& Kalkura, 2001). 

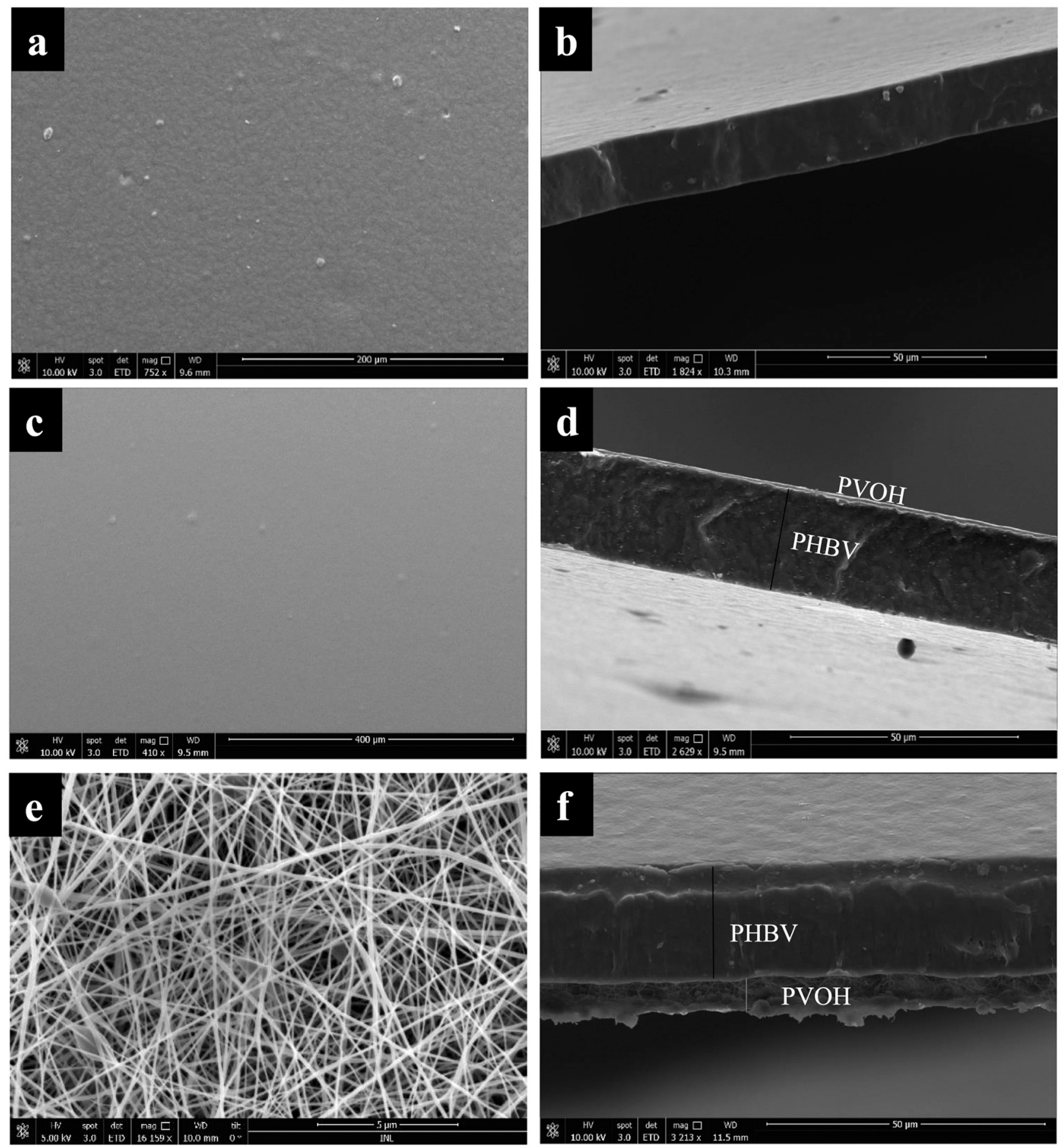

Fig. 2. Selected scanning electron microscopy microphotographs of (a) PHBV film surface (b) PHBV film cross-sectional view (c) PHBV/coating films surface (d) $\mathrm{PHBV} /$ coating films cross-sectional view (e) PHBV/nanofiber films surface (f) PHBV/ nanofiber films cross-sectional view.

Table 3

PVOH weight contribution for the final matrices of PHBV/coating films and $\mathrm{PHBV} /$ nanofiber films.

\begin{tabular}{lll}
\hline Matrix & Weight $(\mathrm{g})$ & PVOH weight $(\%)$ \\
\hline PHBV (control) & $0.061 \pm 0,002 \mathrm{a}$ & NA \\
PHBV/coating films & $0.109 \pm 0,014 \mathrm{~b}$ & 44.04 \\
PHBV/nanofiber films & $0.095 \pm 0.006 \mathrm{~b}$ & 35.79
\end{tabular}

Values reported are the mean \pm standard deviations. Different letters (a-b) in the same column indicate a statistically significant difference between samples $(\mathrm{p}<0.05)$.

\subsection{Differential scanning calorimetry (DSC) and thermogravimetric analyses (TGA)}

All samples show a bimodal endothermic peak in the DSC thermogram. One first melting temperature $\left(\mathrm{T}_{\mathrm{m}}\right)$ close to $140{ }^{\circ} \mathrm{C}$ was observed for all samples, and a second melting peak was observed for PHBV $\left(153.89 \pm 0.35^{\circ} \mathrm{C}\right)$ and the other two matrices (PHBV/coating films and $\mathrm{PHBV} /$ nanofiber films) $\approx 150{ }^{\circ} \mathrm{C}$ (Table 4). For PHBV films, these values present the typical melting temperatures of PHBV (Cerqueira et al., 2016a, 2016b). For the PHBV/nanofiber films and PHBV/coating films, the decrease in both melting temperatures is related to the crystalline phase of $\mathrm{PVOH}$ that will be reflected in the decrease of the melting 
Table 4

Values of elongation-at-break, tensile strength and Young's modulus of PHBV films and PHBV/coating films and PHBV/nanofiber films.

\begin{tabular}{llll}
\hline Matrix & $\begin{array}{l}\text { Tensile strength } \\
(\mathrm{MPa})\end{array}$ & $\begin{array}{l}\text { Elongation-at- } \\
\text { break (\%) }\end{array}$ & $\begin{array}{l}\text { Young's modulus } \\
(\mathrm{MPa})\end{array}$ \\
\hline $\begin{array}{l}\text { PHBV (control) } \\
\mathrm{PHBV} / \text { coating }\end{array}$ & $21.40 \pm 2.04 \mathrm{a}$ & $2.69 \pm 0.32 \mathrm{a}$ & $1335.00 \pm 68.88 \mathrm{a}$ \\
$\quad$ films & & $4.14 \pm 0.36 \mathrm{~b}$ & $987.83 \pm 148.23 \mathrm{~b}$ \\
$\begin{array}{l}\text { PHBV/nanofiber } \\
\quad \text { films }\end{array}$ & $14.25 \pm 2.15 \mathrm{~b}$ & $3.17 \pm 0.60 \mathrm{a}$ & $777.00 \pm 181.88 \mathrm{~b}$ \\
\hline
\end{tabular}

Values reported are the mean \pm standard deviations. Different letters (a-b) in the same column indicate a statistically significant difference between samples $(\mathrm{p}<0.05)$.

\section{temperature.}

Analysis of the melting enthalpy shows significant differences between PHBV, PHBV/nanofiber and PHBV/coating films related to the mass contribution of $\mathrm{PHBV}$ to the system. There is a decrease proportional to the lower PHBV mass proportion (Table 3 ) in the $\mathrm{PHBV} /$ coating films and $\mathrm{PHBV} /$ nanofiber films for the first $\left(\Delta \mathrm{H}_{\mathrm{m} 1}=11.30 \mathrm{~J} \mathrm{~g}^{-1}\right)$ and the PHBV/coating films and PHBV/nanofiber films $\left(\Delta \mathrm{H}_{\mathrm{m} 1} \approx 4 \mathrm{~J} \mathrm{~g}^{-1}\right)$ and second melting enthalpy $\left(\Delta \mathrm{H}_{\mathrm{m} 2}=17.45 \mathrm{~J} \mathrm{~g}^{-1}\right)$ and the PHBV/coating films and PHBV/nanofiber films $\left(\Delta \mathrm{H}_{\mathrm{m} 2} \approx 7 \mathrm{~J} \mathrm{~g}^{-1}\right)$ (Table 5). Table 3 showed that the $\mathrm{PVOH}$ represents $44.04 \%$ of the final weight in $\mathrm{PHBV} /$ nanofiber films and $35.79 \%$ in the $\mathrm{PHBV} /$ coating films. Since the weight of PHBV is approximately $60-65 \%$ compared to PHBV alone, it was expected a decrease in the melting enthalpy, as explained before.

Fig. 4 presents thermal stability obtained by TGA for PHBV film, $\mathrm{PHBV} /$ coating films and $\mathrm{PHBV} /$ nanofiber films, respectively.

PHBV presents one decomposition temperature around $283.37 \pm$ $1.7{ }^{\circ} \mathrm{C}$ that is also present in PHBV/coating films $\left(288.93 \pm 6.14{ }^{\circ} \mathrm{C}\right)$ and $\mathrm{PHBV} /$ nanofiber films $\left(290.5 \pm 3.5^{\circ} \mathrm{C}\right)$ with no statistical differences. Additionally, in the PHBV/coating films and the PHBV/nanofiber films, another decomposition temperature appears related to the presence of $\mathrm{PVOH}$ in the matrix, presenting a statistically different $(p>0.05)$ decomposition temperature of $265.21 \pm 1.15^{\circ} \mathrm{C}$ for $\mathrm{PHBV} /$ coating films and $274.03 \pm 0.35{ }^{\circ} \mathrm{C}$ for $\mathrm{PHBV} /$ nanofiber films. These differences between $\mathrm{PHBV} /$ coating films and $\mathrm{PHBV} /$ nanofiber films can be due to the method used since electrospinning will promote a faster drying while the casting will promote higher crystalization due to a slower drying process, as seen in XRD results.

\subsection{Fourier transform infrared spectroscopy (FTIR)}

Observing the PHBV/coating film's spectra in Fig. 5, it can be observed that the fingerprint vibrations of PHBV are present and represented by peaks in: $1719 \mathrm{~cm}^{-1}$ related to $\mathrm{C}=\mathrm{O}$ stretching vibration of the carbonyl group (Melendez-Rodriguez et al., 2018) from $1226 \mathrm{~cm}^{-1}$ and $1276 \mathrm{~cm}^{-1}$ linked to $-\mathrm{C}-\mathrm{O}-\mathrm{C}$ stretching vibration. Peaks at 1175 $\mathrm{cm}^{-1}$ are related to asymmetric stretching of $\mathrm{C}-\mathrm{O}-\mathrm{C}$, and the peak at $1379 \mathrm{~cm}^{-1}$ is linked to the symmetric wagging of methyl groups (Cherpinski et al., 2017). The presence of $\mathrm{PVOH}$ revealed no interference in the PHBV chemical structure while working as an agent of PHBV film functionalization. The presence of Felix $\mathrm{O} 1$ showed to be irrelevant, probably related to the low percentage used to produce the samples (1\%).

\subsection{Bacteriophage titer in $P H B V /$ coating films and $P H B V /$ nanofiber films}

Felix 01 bacteriophage loaded PHBV/coating films and PHBV/ nanofiber films were produced by adding $1 \%(v / v)$ of Felix $\mathrm{O} 1$ bacteriophage solution to the $\mathrm{PVOH} 14 \%$ solution. The titer in $\mathrm{PHBV} /$ coating films was $1.4 \times 10^{6} \mathrm{PFU} \mathrm{mL}^{-1}$, and in the $\mathrm{PHBV} /$ nanofiber films was 2.6 $\times 10^{6} \mathrm{PFU} \mathrm{mL}{ }^{-1}$. Despite the similarity in titers, these are far different from the theoretical values expected for PHBV/coating films $\left(2.0 \times 10^{7}\right.$ $\left.\mathrm{PFU} \mathrm{mL} \mathrm{m}^{-1}\right)$ and $\mathrm{PHBV} /$ nanofiber films $\left(1.4 \times 10^{8} \mathrm{PFU} \mathrm{mL}^{-1}\right)$. This shows that $1 \log$ is lost in the process for $\mathrm{PHBV} /$ coating films production and 2

Table 5

Values of DSC melting temperature $\mathrm{T}_{\mathrm{m} 1}$ and $\mathrm{T}_{\mathrm{m} 2}$ and melting Enthalpy $\Delta \mathrm{H}_{\mathrm{m} 1}$ and $\Delta \mathrm{H}_{\mathrm{m} 2}$ for PHBV films and PHBV/coating films and PHBV/nanofiber films.

\begin{tabular}{lllll}
\hline Sample & $\mathrm{T}_{\mathrm{m} 1}\left({ }^{\circ} \mathrm{C}\right)$ & $\mathrm{T}_{\mathrm{m} 2}\left({ }^{\circ} \mathrm{C}\right)$ & $\begin{array}{l}\Delta \mathrm{H}_{\mathrm{m} 1}\left(\mathrm{~J} \mathrm{~g}^{-1}\right. \\
\mathrm{PHBV})\end{array}$ & $\begin{array}{l}\Delta \mathrm{H}_{\mathrm{m} 2}\left(\mathrm{~J} \mathrm{~g}^{-1}\right. \\
\mathrm{PHBV})\end{array}$ \\
\hline PHBV (control) & $141.50 \pm$ & $153.89 \pm$ & $11.30 \pm$ & $17.45 \pm$ \\
& $0.35 \mathrm{a}$ & $0.35 \mathrm{a}$ & $0.42 \mathrm{a}$ & $1.15 \mathrm{a}$ \\
PHBV/coating & $138.38 \pm$ & $150.99 \pm$ & $4.60 \pm 0.32 \mathrm{~b}$ & $6.64 \pm 0.98 \mathrm{~b}$ \\
$\quad$ films & $2.61 \mathrm{ab}$ & $2.36 \mathrm{ab}$ & & \\
PHBV/ & $137.18 \pm$ & $149.96 \pm$ & $4.22 \pm 0.62 \mathrm{~b}$ & $7.25 \pm 0.84 \mathrm{~b}$ \\
$\quad$ nanofiber & $1.05 \mathrm{~b}$ & $0.85 \mathrm{~b}$ & & \\
films & & & &
\end{tabular}

Values reported are the mean \pm standard deviations. Different letters $(a-c)$ in the same column indicate a statistically significant difference between samples $(\mathrm{p}<$ 0.05).

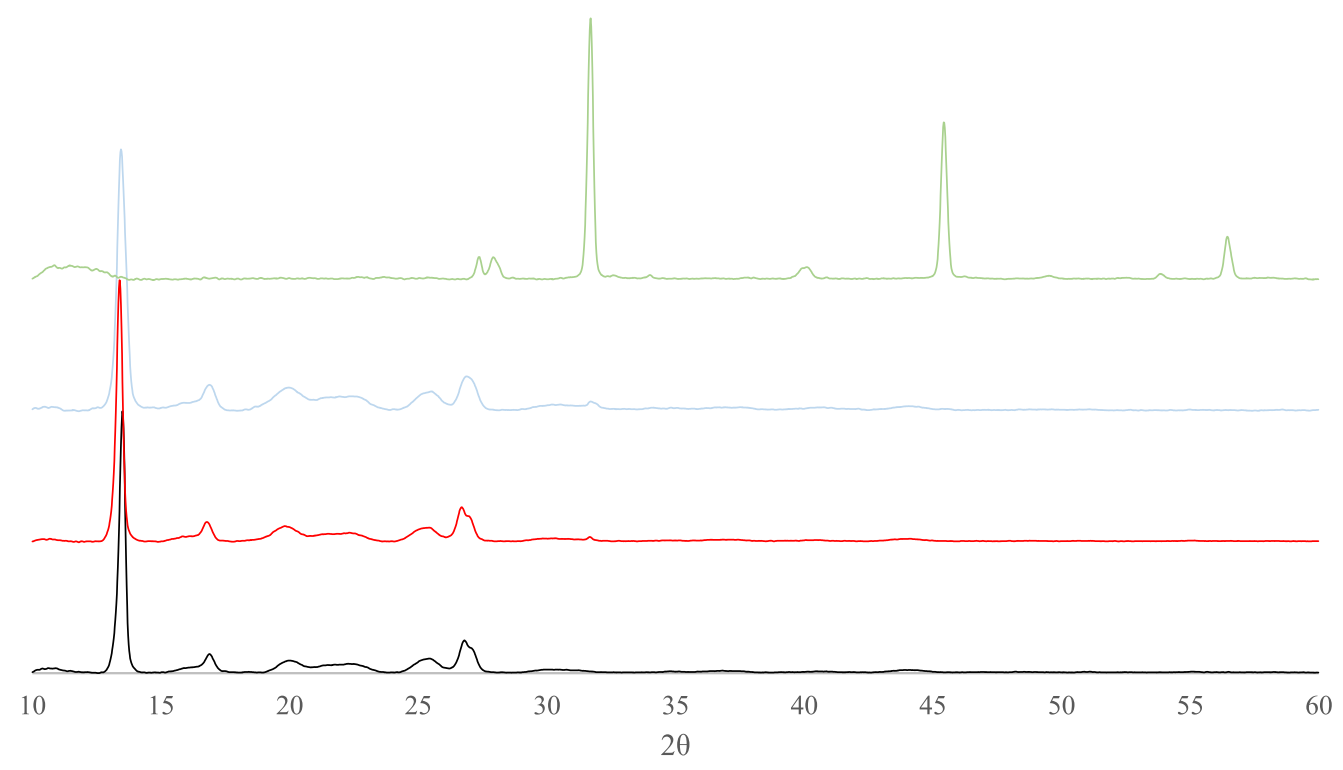

Fig. 3. X-ray diffractograms of PHBV Film (/), PHBV/coating films with FO1(/), and PHBV/nanofiber films with FO1 (/) and FO1 (/). 


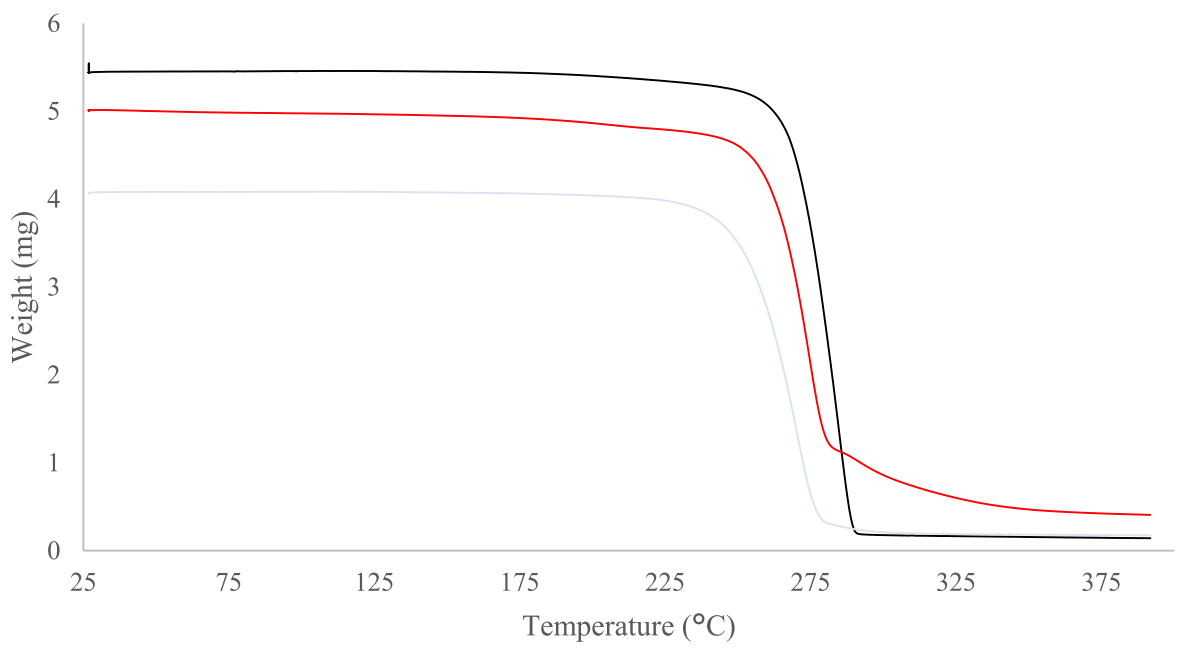

Fig. 4. TGA thermogram average of PHBV film (/), PHBV/coating films with F01(/) and PHBV/nanofiber films with F01(/).

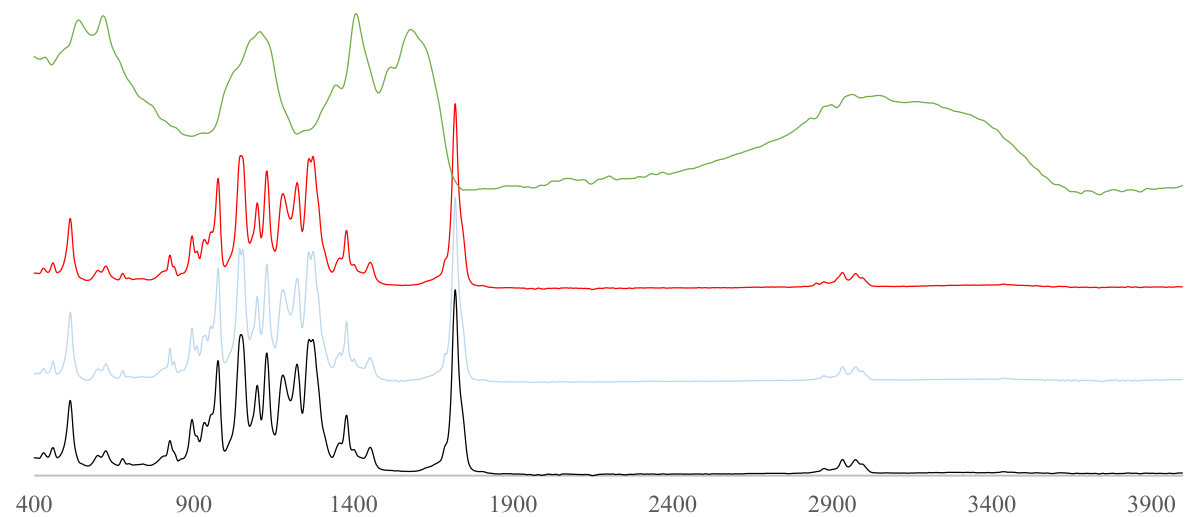

Fig. 5. FTIR spectra of FO1 (/), PHBV film (/), and PHBV/coating films with FO1(/), and PHBV/nanofiber films with FO1 (/).

logs in the PHBV/nanofiber films production. The methodology used for their fabrication could have influenced the phage activity. For instance, the lower experimental titer values in PHBV/coating films may be due to sample loss in the spreading process and a loss in bacteriophage activity during the drying process. On the other hand, the significant difference between the theoretical and experimental values of Felix $\mathrm{O} 1$ in PHBV/ nanofiber films is most certainly related to the fact that a large fraction of nanofibers is electrospun beyond the sample size, and these areas are not sampled. Other few studies tried to incorporate phages in electrospun nanofibers, but the bacteriophage titer loss was significantly higher (8 log) comparing with the results presented above (Korehei \& Kadla, 2013).

Overall, both methods are suitable for the incorporation of Felix O1, preserving its antimicrobial activity. Although still scarce, some studies successfully incorporated bacteriophages into matrices using electrospinning and coating techniques. Radford et al. (2017) used xanthan coatings and PLA films to incorporate bacteriophage Felix $\mathrm{O} 1$ and Listeria phage A551. They developed a coating where $99.99 \%$ of the phage released in $30 \mathrm{~min}$, that significantly inhibited the growth of Salmonella Typhimurium and Listeria monocytogenes in culture and precooked sliced turkey breast over 30 days. Also, Korehei and Kadla (2013) entrapped T4 bacteriophages using a core/shell capsule produced by coaxial electrospinning using polyethylene oxide (PEO) for the shell and a T4 phage/buffer suspension for the core. In vitro studies revealed a burst within 30 min with almost a complete release of the encapsulated T4 phage. The coaxial electrospinning caused no reduction in T4 titer,

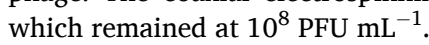

\section{Conclusions}

This work showed that bacteriophage Felix $\mathrm{O} 1$ can be incorporated into different systems produced by spreading and electrospinning and maintain its antimicrobial activity against $S$. Enteritidis. Despite the influence of $\mathrm{PVOH}$ in moisture, solubility, and surface hydrophobicity, there were no major differences in the PHBV chemical structure. It was possible to perform a functionalization of PHBV with two different strategies with good water permeability properties. These results showed that both PHBV/coating films and PHBV/nanofiber films can be used in food products and food packaging to avoid bacterial contaminations, with added antimicrobial potential against Salmonella through the encapsulation of Felix $\mathrm{O} 1$ bacteriophage. This study showed that this novel biodegradable system is a promising solution in the food industry worth exploring.

\section{Declaration of Competing Interest}

The authors declare that they have no known competing financial interests or personal relationships that could have appeared to influence the work reported in this paper. 


\section{Acknowledgments}

This study was supported by the Portuguese Foundation for Science and Technology (FCT) under the scope of the strategic funding of UID/ BIO/04469/2013 unit and COMPETE 2020 (POCI-01-0145-FEDER006684). This project has received funding from the European Union's Horizon 2020 Research and Innovation Programme under grant agreement No 713640. Maria José Costa is recipient of a fellowship supported by a Doctoral Program (SFRH/BD/122897/2016) funded by the Portuguese Foundation for Science and Technology (FCT, POPH-QREN and FSE Portugal). All the bacteriophage solutions were kindly supplied by Micreos (Netherlands).

\section{Appendix A. Supplementary data}

Supplementary data to this article can be found online at https://doi. org/10.1016/j.ifset.2021.102646.

\section{References}

Abd El-aziz, A. M., El-Maghraby, A., \& Taha, N. A. (2017). Comparison between polyvinyl alcohol (PVA) nanofiber and polyvinyl alcohol (PVA) nanofiber/ hydroxyapatite (HA) for removal of $\mathrm{Zn} 2+$ ions from wastewater. Arabian Journal of Chemistry, 10(8), 1052-1060. https://doi.org/10.1016/j.arabjc.2016.09.025

Adams, M. (1959). Bacteriophages. In M. H. Adams (Ed.), Bacteriophages (pp. 450-451). Interscience Publishers. http://www.cabdirect.org/abstracts/19602204111.html.

Ahmadpoor, P., Nateri, A. S., \& Motaghitalab, V. (2013). The optical properties of PVA TiO2 composite nanofibers. Journal of Applied Polymer Science, 130(1), 78-85. https://doi.org/10.1002/app.39147

Alves, D., Cerqueira, M. A., Pastrana, L. M., \& Sillankorva, S. (2020). Entrapment of a phage cocktail and cinnamaldehyde on sodium alginate emulsion-based films to fight food contamination by Escherichia coli and Salmonella Enteritidis. Food Research International, 128(July 2019), 108791. https://doi.org/10.1016/j foodres.2019.108791

Alves, D., Marques, A., Milho, C., Costa, M. J., Pastrana, L. M., Cerqueira, M. A., \& Sillankorva, S. M. (2018). Bacteriophage фIBB-PF7A loaded on sodium alginatebased films to prevent microbial meat spoilage. International Journal of Food Microbiology, 291, 121-127. https://doi.org/10.1016/j.ijfoodmicro.2018.11.026

Azevedo, M. A., Cerqueira, M. A., Fuciños, P., Silva, B. F. B., Teixeira, J. A., \& Pastrana, L. (2020). Rhamnolipids-based nanostructured lipid carriers: Effect of lipid phase on physicochemical properties and stability. Food Chemistry, 344(November 2020), 128670. https://doi.org/10.1016/j.foodchem.2020.128670

Balik, B. A., Argin, S., Lagaron, J. M., \& Torres-Giner, S. (2019). Preparation and characterization of electrospun pectin-based films and their application in sustainable aroma barrier multilayer packaging. Applied Sciences (Switzerland), 9 (23). https://doi.org/10.3390/app9235136

Becerril, R., Nerín, C., \& Silva, F. (2020). Encapsulation systems for antimicrobial food packaging components: An update. Molecules, 25(5). https://doi.org/10.3390/ molecules25051134

Cerqueira, M. A., Costa, M. J., Fuciños, C., Pastrana, L. M., \& Vicente, A. A. (2014). Development of active and nanotechnology-based smart edible packaging systems: Physical-chemical characterization. Food and Bioprocess Technology, 7(5). https:// doi.org/10.1007/s11947-013-1117-5

Cerqueira, M. A., Costa, M. J., Rivera, M. C., Ramos, O. L., \& Vicente, A. A. (2014). Flavouring and coating technologies for preservation and processing of foods. In, Vol. 9781118406. Conventional and advanced food processing technologies. https://doi. org/10.1002/9781118406281.ch12

Cerqueira, M. A., Costa, M. J., Fuciños, C., Pastrana, L. M., \& Vicente, A. A. (2013). Development of active and nanotechnology-based smart edible packaging systems: Physical-chemical characterization. Food and Bioprocess Technology, 7(5), 1472-1482. https://doi.org/10.1007/s11947-013-1117-5

Cerqueira, M. A., Fabra, M. J., Castro-Mayorga, J. L., Bourbon, A. I., Pastrana, L. M., Vicente, A. A., \& Lagaron, J. M. (2016a). Use of electrospinning to develop antimicrobial biodegradable multilayer systems: Encapsulation of cinnamaldehyde and their physicochemical characterization. Food and Bioprocess Technology, 9(11), 1874-1884. https://doi.org/10.1007/s11947-016-1772-4

Cerqueira, M. A., Fabra, M. J., Castro-Mayorga, J. L., Bourbon, A. I., Pastrana, L. M., Vicente, A. A., \& Lagaron, J. M. (2016b). Use of electrospinning to develop antimicrobial biodegradable multilayer systems: Encapsulation of cinnamaldehyde and their physicochemical characterization. Food and Bioprocess Technology, 1-11. https://doi.org/10.1007/s11947-016-1772-4

Cherpinski, A., Jari, S. T., Maria, V., Peresin, S., Lahtinen, P., \& Lagaron, J. M. (2018), Improving the water resistance of nanocellulose-based films with polyhydroxyalkanoates processed by the electrospinning coating technique. Cellulose. https://doi.org/10.1007/s10570-018-1648-Z

Cherpinski, A., Torres-giner, S., Lagaron, J. M., Cabedo, L., \& M, J. A. (2017). Multilayer structures based on annealed electrospun biopolymer coatings of interest in water and aroma barrier fiber-based food packaging applications. Journal of Applied Polymer Science, 45501, 1-11. https://doi.org/10.1002/app.45501
Cho, J. D., Lyoo, W. S., Chvalun, S. N., \& Blackwell, J. (1999). X-ray analysis and molecular modeling of poly(vinyl alcohol)s with different stereoregularities. Macromolecules, 32(19), 6236-6241. https://doi.org/10.1021/ma9908402

Costa, M. J., Marques, A. M., Pastrana, L. M., Teixeira, J. A., Sillankorva, S. M., \& Cerqueira, M. A. (2018). Physicochemical properties of alginate-based films: Effect of ionic crosslinking and mannuronic and guluronic acid ratio. Food Hydrocolloids, 81. https://doi.org/10.1016/j.foodhyd.2018.03.014

Costa, M. J., Cerqueira, M. A., Ruiz, H. A., Fougnies, C., Richel, A., Vicente, A. A., Aguedo, M. (2015). Use of wheat bran arabinoxylans in chitosan-based films: Effect on physicochemical properties. Industrial Crops and Products, 66, 3050311. https:// doi.org/10.1016/j.indcrop.2015.01.003

Costa, M. J., Ramos, P. E., Fuciños, P., Teixeira, J. A., Pastrana, L. M., \& Cerqueira, M. A. (2017). Development of bio-based nanostructured systems by electrohydrodynamic processes. In R. R. Vittal, \& J. A. Bai (Eds.), Nanotechnology Applications in the Food Industry (pp. 3-20). CRC Press.

Fabra, M. J., López-Rubio, A., \& Lagaron, J. M. (2015). Three-layer films based on wheat gluten and electrospun PHA. Food and Bioprocess Technology, 8(11), 2330-2340. https://doi.org/10.1007/s11947-015-1590-0

Figueroa-Lopez, K. J., Enescu, D., Torres-giner, S., Cabedo, L., Cerqueira, M. A., Pastrana, L., ... Lagaron, J. M. (2020). Development of electrospun active films of poly (3-hydroxybutyrate- co -3-hydroxyvalerate) by the incorporation of cyclodextrin inclusion complexes containing oregano essential oil. Food Hydrocolloids, 108(May). https://doi.org/10.1016/j.foodhyd.2020.106013

Freitas, F. M. C., Cerqueira, M. A., Gonçalves, C., Azinheiro, S., Garrido-Maestu, A., Vicente, A. A., ... Michelin, M. (2020). Green synthesis of lignin nano- and microparticles: Physicochemical characterization, bioactive properties and cytotoxicity assessment. International Journal of Biological Macromolecules, 163, 1798-1809. https://doi.org/10.1016/j.ijbiomac.2020.09.110

Hirsch, E., Vass, P., Démuth, B., Pethő, Z., Bitay, E., Andersen, S. K., ... Marosi, G. (2019). Electrospinning scale-up and formulation development of PVA nanofibers aiming oral delivery of biopharmaceuticals. Express Polymer Letters, 13(7), 590-603. https:// doi.org/10.3144/expresspolymlett.2019.50

Hirsh, D. C., \& Martin, L. D. (1983). Bacteriophage and high-performance liquid chromatography. 45(1) pp. 260-264).

Huang, K., \& Nitin, N. (2019). Edible bacteriophage based antimicrobial coating on fish feed for enhanced treatment of bacterial infections in aquaculture industry. Aquaculture, 502(September 2018), 18-25. https://doi.org/10.1016/j. aquaculture.2018.12.026

Jost, V., \& Langowski, H.-C. (2015). Effect of different plasticisers on the mechanical and barrier properties of extruded PHBV cast films. European Polymer Journal, 68, 302-312. https://doi.org/10.1016/j.eurpolymj.2015.04.012

Kallings, L. O. (1967). Sensitivity of various salmonella strains to felix 0-1 phage (pp. 446-454).

Kim, S., Jo, A., \& Ahn, J. (2015). Application of chitosan-alginate microspheres for the sustained release of bacteriophage in simulated gastrointestinal conditions. International Journal of Food Science and Technology, 50(4), 913-918. https://doi.org/ $10.1111 / \mathrm{ijfs} .12736$

Korehei, R., \& Kadla, J. (2013). Incorporation of T4 bacteriophage in electrospun fibres. Journal of Applied Microbiology, 114(5), 1425-1434. https://doi.org/10.1111/ jam.12158

Kotnis, M. A., O’Brien, G. S., \& Willett, J. L. (1995). Processing and mechanical properties of biodegradable poly(hydroxybutyrate-co-valerate)-starch compositions. Journal of Environmental Polymer Degradation, 3(2), 97-105. https://doi.org/ 10.1007/BF02067485

Lee, H., Yamaguchi, K., Nagaishi, T., Murai, M., Kim, M., Wei, K., ... Kim, I. S. (2017). Enhancement of mechanical properties of polymeric nanofibers by controlling crystallization behavior using a simple freezing/thawing process. RSC Advances, 7 (69), 43994-44000. https://doi.org/10.1039/c7ra06545k

López-Rubio, A., Sanchez, E., Sanz, Y., \& Lagaron, J. M. (2009). Encapsulation of living bifidobacteria in ultrathin PVOH electrospun fibers. Biomacromolecules, 10, 2823-2829.

Malik, D. J., Sokolov, I. J., Vinner, G. V., Mancuso, F., Cinquerrui, S., Vladisavljevic, G. T., ... Stapley, A. G. F. (2017). Formulation, stabilisation and encapsulation of bacteriophage for phage therapy. Advances in Colloid and Interface Science. https://doi.org/10.1016/j.cis.2017.05.014

Malik, D. J., Sokolov, I. J., Vinner, G. K., Mancuso, F., Cinquerrui, S., Vladisavljevic, G. T., ... Kirpichnikova, A. (2017). Formulation, stabilisation and encapsulation of bacteriophage for phage therapy. Advances in Colloid and Interface Science, 249(May), 100-133. https://doi.org/10.1016/j.cis.2017.05.014

Massaro, C., Cosentino, F., Terzi, R., Marcianò, T., \& Capodieci, L. (2015). Smart poly (lactic acid) -functionalized films with cardanol-based nanovesicles obtained from renewable resources for food packaging application. In 1st workshop on nanotechnology in instrumentation and measurement (pp. 212-215).

Melendez-Rodriguez, B., Castro-Mayorga, J. L., Reis, M. A. M., Sammon, C., Cabedo, L., Torres-Giner, S., \& Lagaron, J. M. (2018). Preparation and characterization of electrospun food biopackaging films of poly(3-hydroxybutyrate-co-3hydroxyvalerate) derived from fruit pulp biowaste. Frontiers in Sustainable Food Systems, 2(July), 1-16. https://doi.org/10.3389/fsufs.2018.00038

Nunes, R., Pereira, B. D. A., Cerqueira, M. A., Silva, P., Pastrana, L. M., Vicente, A. A., . Bourbon, A. I. (2020). Lactoferrin-based nanoemulsions to improve the physical and chemical stability of omega-3 fatty acids. Food and Function, 11(3), 1966-1981. https://doi.org/10.1039/c9fo02307k

Ortiz de Elguea-Culebras, G., Bourbon, A. I., Costa, M. J., Muñoz-Tebar, N., Carmona, M., Molina, A., ... Vicente, A. A. (2019). Optimization of a chitosan solution as potential carrier for the incorporation of Santolina chamaecyparissus L. solid by-product in an 
edible vegetal coating on "Manchego" cheese. Food Hydrocolloids, 89. https://doi. org/10.1016/j.foodhyd.2018.10.054

Peris, R. R. (2018). Doctoral thesis - Multilayer biodegradable active films based on phbv for food packaging (issue September). Uuniversitat Politècnica de València.

Radford, D., Guild, B., Strange, P., Ahmed, R., Lim, L. T., \& Balamurugan, S. (2017) Characterization of antimicrobial properties of Salmonella phage Felix O1 and Listeria phage A511 embedded in xanthan coatings on poly(lactic acid) films. Food Microbiology, 66, 117-128. https://doi.org/10.1016/j.fm.2017.04.015

Ramalingom, S., Podder, J., \& Kalkura, S. N. (2001). Crystallization and characterization of $\beta-\mathrm{MgSO} 4 \cdot 7 \mathrm{H} 2 \mathrm{O}$. Crystal Research and Technology, 36, 1357-1364.

Ribeiro, C., Costa, C. M., Correia, D. M., Nunes-Pereira, J., Oliveira, J., Martins, P., ... Lanceros-Méndez, S. (2018). Electroactive poly(vinylidene fluoride)-based structures for advanced applications. Nature Protocols, 13(4), 681-704. https://doi.org/ $10.1038 /$ nprot.2017.157

Taylor, T. M. (2018). Natural food antimicrobials: recent trends in their use, limitations, and opportunities for their applications in food preservation. In X. Fan, H. Ngo, \& C. Wu (Eds.), Natural and bio-based antimicrobials for food applications (pp. 25-43). ACS Publications.

Salalha, W., Kuhn, J., Dror, Y., \& Zussman, E. (2006). Encapsulation of bacteria and viruses in electrospun nanofibres. Nanotechnology, 17(18), 4675-4681. https://doi org/10.1088/0957-4484/17/18/025

Sillankorva, S. M., Oliveira, H., \& Azeredo, J. (2012a). Bacteriophages and their role in food safety. International Journal of Microbiology, 2012. https://doi.org/10.1155/ 2012/863945

Sillankorva, S. M., Oliveira, H., \& Azeredo, J. (2012b). Bacteriophages and their role in food safety. International Journal of Microbiology, 2012. https://doi.org/10.1155/ 2012/863945

Śliwka, P., Mituła, P., Mituła, A., Skaradziński, G., Choińska-Pulit, A., Niezgoda, N., Weber-Dąbrowska, B., Żaczek, M., \& Skaradzińska, A. (2019). Encapsulation of bacteriophage T4 in mannitol-alginate dry macrospheres and survival in simulated gastrointestinal conditions. Lwt, 99(September 2018), 238-243. https://doi.org/ 10.1016/j.lwt.2018.09.043

Wang, P., Li, Y., Zhang, C., Que, F., Weiss, J., \& Zhang, H. (2020). Characterization and antioxidant activity of trilayer gelatin/dextran-propyl gallate/gelatin films: Electrospinning versus solvent casting. Lwt, 128(March), 109536. https://doi.org/ 10.1016/j.lwt.2020.109536

Weiss, J., Kanjanapongkul, K., Wongsasulak, S., \& Yoovidhya, T. (2014). Electrospun fibers: Fabrication, functionalities and potential food industry applications. In Q. Huang (Ed.), Nanotechnology in the food, beverage and nutraceutical industries (pp. 362-397). Woodhead Publishing Limited. https://doi.org/10.1007/s13398-014. 0173-7.2.

Wen, P., Zhu, D.-H., Wu, H., Zong, M.-H., Jing, Y.-R., \& Han, S.-Y. (2016). Encapsulation of cinnamon essential oil in electrospun nanofibrous film for active food packaging. Food Control, 59, 366-376. https://doi.org/10.1016/j.foodcont.2015.06.005

World Health Organization. (2018, February). Salmonella (non-typhoidal). https://www.who.int/news-room/fact-sheets/detail/salmonella-(non-typhoidal).

World Health Organization. (2020, April). Food safety. https://www.who.int/NEWS -ROOM/FACT-SHEETS/DETAIL/FOOD-SAFETY.

Yousefi, M., Ehsani, A., \& Jafari, S. M. (2019). Lipid-based nano delivery of antimicrobials to control food-borne bacteria. Advances in Colloid and Interface Science, 270, 263-277. https://doi.org/10.1016/j.cis.2019.07.005

Yu, H. Y., Qin, Z. Y., Sun, B., Yang, X. G., \& Yao, J. M. (2014). Reinforcement of transparent poly(3-hydroxybutyrate-co-3-hydroxyvalerate) by incorporation of functionalized carbon nanotubes as a novel bionanocomposite for food packaging. Composites Science and Technology, 94, 96-104. https://doi.org/10.1016/j. compscitech.2014.01.018 